\title{
Seroprevalence of HBV and HCV in primary hepatocellular carcinoma patients in Zimbabwe Nyasha Chin'ombe ${ }^{* \dagger 1,2}$, Evans Chavhunduka ${ }^{\dagger 2,3}$ and Hilda T Matarira ${ }^{2,4}$
}

Address: ${ }^{1}$ University of Cape Town, Faculty of Health Sciences, Department of Clinical Laboratory Sciences, Division of Medical Virology, Observatory 7925, Cape Town, South Africa, ${ }^{2}$ University of Zimbabwe, Faculty of Health Sciences, Department of Chemical Pathology, PO Box A178 Avondale, Harare, Zimbabwe, ${ }^{3}$ University of Zimbabwe, Faculty of Veterinary Sciences, PO Box MP167 Mount Pleasant, Harare, Zimbabwe and ${ }^{4}$ Great Zimbabwe University, Box 1460, Masvingo, Zimbabwe

Email: Nyasha Chin'ombe* - Nyasha.Chinombe@uct.ac.za; Evans Chavhunduka - echavas2002@yahoo.co.uk; Hilda T Matarira - chempath@medsch.uz.ac.zw

* Corresponding author †Equal contributors

Published: 8 October 2009

Infectious Agents and Cancer 2009, 4:15 doi:10.1186/1750-9378-4-15
Received: 8 May 2009

Accepted: 8 October 2009

This article is available from: http://www.infectagentscancer.com/content/4/1/15

(C) 2009 Chin'ombe et al; licensee BioMed Central Ltd.

This is an Open Access article distributed under the terms of the Creative Commons Attribution License (http://creativecommons.org/licenses/by/2.0), which permits unrestricted use, distribution, and reproduction in any medium, provided the original work is properly cited.

\begin{abstract}
Background: Primary hepatocellular carcinoma (PHC) is one of the most common cancers in Zimbabwe. Hepatitis $B$ virus (HBV) and hepatitis $\mathrm{C}$ virus $(\mathrm{HCV})$ are suspected to play a major role in causing this cancer. The objective of this study was to determine the seroprevalence of $\mathrm{HBV}$ and $\mathrm{HCV}$ in PHC at Parirenyatwa Referral Hospital in Zimbabwe. We evaluated the serological markers of the two viruses in patients with PHC using commercially available enzyme-linked immunosorbent kits.
\end{abstract}

Results: Out of the 60 patients with PHC, $48.3 \%$ were seropositive for HBV and $20.0 \%$ were seropositive for HCV. Co-infection by HCV and HBV was found in $8 \%$ of the patients. Only $13.3 \%$ of the health controls (blood donors) were positive for HBV. All the controls were negative for $\mathrm{HCV}$.

Conclusion: The high seropositivity of HBV and HCV in PHC in Zimbabwe suggested that the two viruses were a major cause of the cancer.

\section{Background}

Liver cancer is one of the most common cancers in Zimbabwe and Africa $[1,2]$. Hepatitis B virus (HBV) and hepatitis $\mathrm{C}$ virus (HCV) are suspected to play an important aetiological role in liver cancer in this region and the continent. HBV is a partially double-stranded DNA virus and is an important cause of morbidity and mortality worldwide $[3,4]$. Globally, it is estimated that about 2 billion people have been infected with HBV and about 350 million people are chronically infected [5]. Most of the chronically-infected people are found in developing countries and are at a high-risk of developing liver cirrho- sis and hepatocellular carcinoma [6,7]. Areas with high prevalence of HBV include Southeast Asia, China and Africa, where approximately $10 \%$ of the population are chronic carriers $[5,8]$. In persons infected with HBV, morbidity and mortality result when inflammatory liver disease progresses to cirrhosis and primary hepatocellular carcinoma [8]. High-risk groups of HBV infection include intravenous drug users, attendees of sexually transmitted disease clinics, homosexual men, patients undergoing haemodialysis, children born to mothers who are hepatitis B surface antigen positive and health care workers $[6,7,9]$. 
$\mathrm{HCV}$ is a positive-stranded RNA virus which belongs to the Flaviviridae family [10]. Worldwide, the virus infects about 170 million people [11]. Infection by this virus can be resolved spontaneously in only about $15-20 \%$ of cases and chronic infection is established in the remaining 80$85 \%$ [12]. Most of these chronic HCV infections usually lead to severe hepatitis, liver cirrhosis and hepatocellular carcinoma [13-17]. The risk of developing PHC ranges from $1-5 \%$ after about two decades of chronic infection [18]. HCV infection usually occurs following direct parenteral exposure to contaminated body fluids, especially blood $[16,19]$. The prevalence of both HBV and $\mathrm{HCV}$ in PHC in Zimbabwe is poorly known. It was against this background that we set out to evaluate the presence of antibodies to HBV surface antigen and HCV in patients with PHC at Parirenyatwa Central Hospital in Zimbabwe.

\section{Results \\ Patient data}

Data from hospital records showed that all the patients presented with abdominal distending discomfort, characterised by right upper quadrant pain and hepatic mass enlargement in some cases. Weight loss was observed in all the patients with almost a third showing that they were jaundiced. Ascites and fever symptoms were not uncommon in the patients on presentation or during hospitalisation. All the patients had impaired liver function in one or more of serum aminotransferases, prolonged prothrombin time and albumin levels. Out of the 60 patients, $53(88 \%)$ had serum gamma-glutamyl transferase (GGT) levels above the reference range, with 10 of them having GGT values greater than $200 \mathrm{IU} / \mathrm{L}$. Of all the patients, 30 (50\%) had alanine transaminase (ALT) levels elevated above the upper limit of normal range. The age ranges of patients and controls are given in Table 1.

The clinical management of the patients was also assessed from the records. Most of the patients were of poor social background, either in the lowest income group or not employed at all. Some of the males $(n=11)$ over 30 years of age had a history of alcohol drinking. Of all the patients, $7(12 \%)$ had cirrhosis clearly indicated in their records. Alpha-fetoprotein (AFP) levels were greater than $400 \mathrm{ng} / \mathrm{ml}$ in 33 patients (55\%) and 21 patients (35\%) with AFPs less than $400 \mathrm{ng} / \mathrm{ml}$ had confirmation of PHC by ultrasound and cytology. The difference in age distribution in PHC patients and health individual controls was not significant $(\mathrm{p}>0.05)$. The difference in sex between the two groups was also not significantly different $(\mathrm{p}>$ $0.05)$.

\section{HBsAg and HCV antibody status in PHC patients}

The seroprevalence of HBV and HCV in patients with PHC and health blood donours is summarized in Table 2. Of the 60 PHC cases, 29 patients (48\%) were positive for HBsAg of which 7 were females and 22 were males. The age range of patients was $18-70$ years and the mean was 43.8 years. Only 10 (34\%) of the patients were over 45 years of age. The mean age of HBsAg negative patients was 47.6 years. There was no significant discrepancy between the mean ages of HBsAg positive and negative patients. Only 4 control subjects were positive for HBsAg. The relative risk for developing PHC in patients with HBsAg was high when control subjects were considered as a reference group (odds ratio $=1.62,95 \%$ CI 0.69-1.64) .

A total of $12(20 \%)$ PHC patients were positive for antiHCV and $8(67 \%)$ of these patients were over 45 years of age $(66.7 \%)$ and the other remaining 4 (33\%) were below 45 years. All the control patients from blood donors were negative for anti-HCV antibodies. The difference in males and females infected with HCV was not significant ( $\mathrm{p}>$ 0.05). The mean age of patients who were positive for anti-HCV was 51.26 years and the age range was $16-70$ years. The odds ratio or relative risk for the development of PHC in anti-HCV positive patients could not be ascertained because none of the control individuals was positive and the calculation required an integer for the reference sample. Of the 12 patients who were anti-HCVpositive, 4 had AFP levels greater than $400 \mathrm{ng} / \mathrm{ml}$ whilst two had their AFP levels within the normal range (0-10 $\mathrm{ng} / \mathrm{ml}$ ). The prevalence of HBsAg was significantly higher than that of anti- HCV both in PHC patients and controls $(\mathrm{p}<0.05)$. The presence of both anti-HCV and HBsAg was noted in 5 patients. It was also noted that more than half of the patients had infection with HBV and/or HCV.

The relative risk of developing PHC was strongly associated with HBV infection. The unadjusted odds ratio for PHC development was high $(1.615 ; 95 \%$ CI 0.69 - 1.65) for overall HBV infection. For those patients with HBsAg alone, the risk for PHC development, using the cases which were negative for HBsAg as a reference group and healthy individuals as controls, was still high (odds ratio

Table I: Sex and age parameters for PHC patients and health controls

\begin{tabular}{lll}
\hline Parameter & PHC patients $(\mathbf{n}=\mathbf{6 0})$ & Health Controls $(\mathbf{n}=\mathbf{3 0})$ \\
\hline Age range & $16-81$ years & $16-69$ years \\
Mean age & 45.7 years & 38.5 years \\
Male to Female ratio & $2: 1$ & $2.08: 1$ \\
\hline
\end{tabular}


Table 2: Seropositivity and negativity for Anti-HCV and HBsAg in PHC and health blood donors

\begin{tabular}{llll}
\hline Parameter & PHC $(\mathbf{n}=\mathbf{6 0})$ & Control s $(\mathbf{n}=\mathbf{3 0})$ & P value \\
\hline Anti-HCV positivity & $12(20 \%)$ & $0(0 \%)$ & $<0.05$ \\
Anti-HCV negativity & $48(80 \%$ & $30(100 \%)$ & $<0.05$ \\
HBsAg positivity & $29(48.3 \%)$ & $4(13.3 \%)$ & $<0.05$ \\
HBsAg negativity & $31(51.7 \%)$ & $26(86.7 \%)$ & $<0.05$ \\
Dual anti-HCV \& HBsAg positivity & $5(8.3 \%)$ & $0(0 \%)$ & - \\
Anti-HCV and/or HBsAg positivity & $36(60 \%)$ & $4(13.3 \%)$ & - \\
Anti-HCV and/or HBsAg negativity & $24(40 \%)$ & $26(86.7 \%)$ & - \\
\hline
\end{tabular}

= 1.48: 95\% CI 0.81-1.53). The relative risk for PHC developing in dual infection with HCV using non-HBsAg cases as references and healthy individuals as controls, was low (odds ratio $=0.818$ ). The odds ratio in patients positive for either anti-HCV and HBsAg or both was even higher (odds ratio $=1.875 ; 95 \%$ CI $0.54-1.88$ ).

\section{Discussion}

Parirenyatwa Hospital is a supra-referral hospital in Zimbabwe. Patients suspected to have primary hepatocellular carcinoma are referred from primary hospitals and clinics around the country to this referral hospital. Therefore, although our study had only 60 PHC patients, they were likely to be representative of the whole country. This study strongly suggested that Hepatitis $\mathrm{B}$ and $\mathrm{C}$ viruses were important etiological factors of PHC in Zimbabwe. Although other factors such as exposure to aflatoxins (from mouldy grains and cereals) and alcohol consumption were believed to be important, hospital records for most of the patients lacked the information. Alcohol consumption was documented in only $20 \%$ of the patients. Information on risks to $\mathrm{HBV}$ and $\mathrm{HCV}$ infection such as history of blood transfusion, use of intravenous drug abuse and traditional surgical procedures could also not be obtained from the files. These parameters could have some influence on the prevalence of seropositivity of PHC patients to HBV and HCV. Aminotrasferase levels were assessed in the records and most patients had abnormal levels of one or more of ALT, AST and GGT being elevated. This is in agreement with studies that showed extensive hepatocellular damage in PHC patients [20-23]. All the patients who were positive for anti-HCV and HBsAg had elevated hepatic enzymes. Albumin was low and prothrombin time was prolonged in most of the cases. Hepatic aminotransferases were not measured in the controls to evaluate hepatocyte damage in those who were HBsAg-positive. There is a strong link between HCV and cirrhosis with $60-80 \%$ of HCV-positive PHC patients being cirrhotic [24-26]. It could have been interesting to note this association in cirrhotic HCV positive PHC cases. Only seven of the patients whose cirrhotic condition was well documented were in the study and anti-HCV antibodies were only found in two patients who also had HBsAg in their sera. The cirrhotic condition of other patients could not be established and hence an association with HCV could not be studied. The biopsy rate is low due to poor prognosis and late presentation. Only 6 patients had histologically verified PHC status. The diagnosis of PHC based on biochemical evaluation of AFP is controversial especially when levels less than $400 \mathrm{ng} / \mathrm{ml}$ are encountered. AFP levels were greater than $400 \mathrm{ng} / \mathrm{ml}$ in 33 patients, six had histological proof and the remainder were confirmed by cytology and ultrasound scanning when focal or multifocal lesions were suggested. The diagnosis techniques employed were convincing that the cases certainly had PHC.

The risks of acquiring HBV and HCV infection could not be assessed for this study. The detection of viral markers in two female teenagers with PHC suggested that they could have acquired the viruses parenterally or vertically. In previous studies of $\mathrm{PHC}$, anti-HCV and HBsAg have been found in even younger patients of 16 years by biopsy $[20,27]$. The mean age of PHC patients of 45.7 years in our study agreed well with those found in studies in South Africa ( 45 years), Nigeria (46.7 years) and Southern Africa $(44.8$ years) $[20,23,27]$. In Mozambique the mean age in Shangaan ethnic group was 33.4 years and $50 \%$ of the patients were below 30 years [21].

The presence of antibodies to the HBsAg in some of the PHC patients clearly indicated HBV infection. The presence of HBsAg is normally used as a diagnostic marker to indicate acute or chronic infection [28]. It could have been interesting if we had also looked at the presence of HBV DNA in the samples. However, in highly endemic areas, HBV DNA has also been detected in blood or liver of patients without HBsAg [29]. The diagnosis of HBV by detection of HBsAg is very reliable only in acute phase infection and present infection $[27,30]$. It is not indicative of past infection. However most of the PHC studies done showed that HBsAg is expressed in $70-80 \%$ of HBV positive patients who were found to be positive for viral DNA $[30,31]$. The reliability of HBsAg as a marker of HBV infection in PHC is based on the expression of this antigen from the integrated viral genome in the hepatocyte DNA during vigorous active hepatocyte proliferation and turnover. At least $80 \%$ of HBsAg carriers have evidence of 
chromosomal integration of viral sequences, by Southern hydridisation of tumour DNA $[31,32]$. Other markers that show past infection could have been assayed for to evaluate overall exposure. Our results confirmed previous reports of high prevalence of HBsAg in patients with PHC in sub-Sahara Africa, especially the southern parts $[20,27,33]$.

The presence of antibodies to HCV in some of the patients also suggested that the virus was also an important aetiological agent in PHC in Zimbabwe. It was not clear whether some of the patients with anti-HCV had already resolved the virus. The resolution of HCV infection occurs in $15-20 \%$ of patients $[12,34]$. It could have been an interesting study if we had also looked at the presence of HCV RNA in the samples. However, it takes between a decade and three for the development of PHC from time of infection with HCV and the viral RNA may disappear upon resolution but the antibodies persist $[35,36]$. Detection of viraemia by polymerase chain reaction (PCR) could also have been done to detect cases where there was active viral replication.

In our study, $48.3 \%$ of 60 PHC patients were HBsAg positive and $20 \%$ were anti-HCV positive. In a previous study in Zimbabwe, HBsAg was detected in $42.6 \%$ of the PHC patients of the 62 patients studied [33]. Positivity for antiHCV was in $23.8 \%$ using a lesser sensitive and specific second generation assay [33]. The two studies show that HBV remains the major infection of hepatitis viruses in the region. The prevalence of HBsAg in controls $(13.3 \%)$ was less than the prevalence of $24.2 \%$ observed in a study of 660 health individuals $[37,38]$. This probably was due to the smaller proportion of the present study group (30 blood donors). The observation of no anti-HCV positive cases in controls is agreement with data from the National Blood Transfusion Service which show a prevalence of less than $1 \%$ in healthy blood donors. However, another study in Zimbabwe has observed an anti-HCV seropositivity of $8 \%$ in healthy rural individuals [22]. Co-infection by HCV and HBV was found in this study. Although HBV and HCV may be independent risk factors of PHC, dual infection is likely to increase the risk of primary hepatocellular carcinogenesis. Some studies have also reported dual infection by HBV and HCV in PHC $[20,23,30]$. However, the absence of serological markers for either HBV and/or HCV in PHC in some PHC patients could not rule out the role of the two viruses in carcinogenesis. Studies have shown that hepatic tissues could have viral genomic sequences in one-third or more of the serologically negative subjects [38]. It was also suspected that aflatoxin contamination could also have played a significant role in PHC development since Zimbabwe has been found to have this post-harvest problem [39]. This study and previous ones, therefore, demonstrate that HBV and HCV are important factors in chronic liver disease and subsequently PHC development in Southern Africa.

\section{Conclusion}

HBV and HCV play a significant role in the aetiology of hepatocellular carcinoma in Zimbabwe.

\section{Patients and Methods Study subjects}

The sixty patients were presented to Parirenyatwa Hospital between October 1999 and August 2000 and were diagnosed as having PHC. Sera for the patients were collected from the Radioimmunoassay (RIA) Laboratory of the Public Health Laboratory (PHL). The serum samples were collected after determination of the levels of the tumour marker, Alpha-fetoprotein (AFP). The sera were stored at $20^{\circ} \mathrm{C}$ until assayed for anti-HCV antibodies and HBsAg. The medical records of the patients were also examined for diagnostic tests and evaluations suggesting or confirming primary hepatocellular carcinoma. The tests included ultrasound scanning, X-ray photography, needle aspirate cytological proof and liver biopsy histology. Of the 60 patients recruited in this study, only 6 had liver biopsy evaluation of PHC by histological examination. The rest of the patients' diagnosis depended on ultrasound scanning, cytology (fine needle aspirate), clinical features and biochemical evaluations of liver functions and AFP levels. Data on age and sex were also extracted. Controls (health blood donors) $(\mathrm{n}=30)$ were included in the study. They were mainly health blood donors from the National Blood Transfusion Services.

\section{Laboratory tests of anti-HCV and anti-HBV serological markers}

All samples (patients and controls) were tested for the anti-HCV using the commercially available MUREX antiHCV (Version 4.0) kit (Abbott Diagnostic Division, RSA) according to manufacturer's instructions. The MUREX anti-HCV (Version 4.0) is a third generation solid phase enzyme immunoassay in which a mixture of highly purified viral antigens is coated into microwells of a microtitre plate. The antigens contain sequences from the core (Structural), NS3 protease/helicase (non-structural), NS4 (non-structural) and the NS5 replicase (non-structural) regions of HCV. During incubation with samples any antiHCV antibodies present in the sample will bind to the immobilized antigens. Following washing to remove unbound material, the captured anti-HCV antibodies are incubated with peroxidase conjungated monoclonal antihuman IgG. The conjugate will bind to the immobilized anti-HCV through the anti-human IgG moiety. After removal of excess conjugate, bound enzyme is detected by the addition of a solution containing 3,3;5,5-tetramethyl benzidine (TMB) and hydrogen peroxide. The enzyme peroxidase changes the substrate to a purple colour in the 
wells, which contain anti-HCV positive samples. The enzymatic reaction is terminated with sulphuric acid to give an orange colour that is read spectrophotometrically. The amount of conjugate bound and hence colour in the wells, is directly proportional to the concentration of antibodies to HCV in the specimen.

All the samples were also tested for HBsAg using the Bioelisa Kit (Biokit, RSA) according to manufacturer's instructions. The Bioelisa Kit is an ELISA test kit for the detection of the hepatitis B surface antigen (HBsAg) in human sera or plasma. The bioelisa HBsAg assay is a direct immunoenzymatic method of the "sandwich" type in which guinea pig anti-HBs antibodies coated onto microtitre plate wells act as the capture antibody and goat anti-HBs anti-bodies marked with peroxidase serve as conjugate antibodies. During the test procedure, the sample to be analysed is incubated in one of the antibody coated wells. If the sample contains HBsAg, the antigen will bind to the antibody on the plate. After washing to eliminate any unbound material, goat anti-HBs conjugate is added to the well and allowed to react with the antigen-antibody complex formed in the first incubation. After a second incubation and subsequent washing, an enzyme substrate solution containing a chromogen (TMB) is added. This solution will develop a blue colour if the sample is HBsAg positive. The blue colour changes to yellow after blocking with sulphuric acid and can be read spectrophotometrically. The intensity of the colour is proportional to the amount of HBsAg in the test specimens.

The results were analysed. Continuous variables were compared using the Student's t-test. Categorical data were compared using the Pearson's Chi-squared test or Fisher's exact test. P-values $<0.05$ were considered statistically significant. Statistical analyses were performed using the Epiinfo program, version 2000 package.

\section{Abbreviations}

HBV: Hepatitis B virus; HBsAg: Hepatitis B surface antigen; HCV: Hepatitis C virus; PHC: primary hepatocellular carcinoma; AFP: alpha-fetoprotein; ALT: alanine transaminase; AST: aspartate transaminase; GGT: gamma glutamyl transpeptidase.

\section{Competing interests}

The authors declare that they have no competing interests.

\section{Authors' contributions}

$\mathrm{NC}$ and EC collected patient specimens, designed and performed the experiments and analyzed the data. HTM participated in the designing of the whole study. All the authors participated in the writing of this manuscript. All the authors read and approved the manuscript.

\section{Acknowledgements}

We thank the medical staff from the RIA Laboratory of the Public Health Laboratory of Parirenyatwa Hospital for assisting us in collection of patient specimens which were used in the study. We also thank the staff from the Zimbabwe National Blood Transfusion Services for providing specimens used as controls in the study. We also extend our heartfelt gratitude to patients whose samples were used in the study. This work was supported financially by a grant from the University of Zimbabwe Research Board.

\section{References}

I. Chokunonga E, Levy LM, Bassett MT, Mauchaza BG, Thomas DB, Parkin DM: Cancer incidence in the African population of Harare, Zimbabwe: second results from the cancer registry 1993-1995. Int J Cancer 2000, 85:54-59.

2. Parkin DM, Sitas F, Chirenje M, Stein L, Abratt R, Wabinga H: Cancer in Indigenous Africans--burden, distribution, and trends. Lancet Oncol 2008, 9:683-692.

3. Chen CJ, Yang HI, Su J, Jen CL, You SL, Lu SN, Huang GT, lloeje UH: REVEAL-HBV Study Group. Risk of hepatocellular carcinoma across a biological gradient of serum hepatitis $B$ virus DNA level. JAMA 2006, 295:65-73.

4. Lok AS: Chronic hepatitis B. N Engl J Med 2000, 346: I682-I683.

5. World Health Organization: Hepatitis B 2000. Factsheet no. 204

6. Lavanchy D: Worldwide epidemiology of HBV infection, disease burden, and vaccine prevention. J Clin Virol 2005, 34(SI):SI-3.

7. Fattovich G, Bortolotti F, Donato F: Natural history of chronic hepatitis B. J Hepatol 2008, 48:335-352.

8. Malik AH, Lee WM: Chronic Hepatitis B virus infection: Treatment strategies for the next millenium. Ann Intern Med 2000, |32:723-73|.

9. Ratinam $D$, Siervert $W$ : Using natural history to guide management of chronic hepatitis B. Modern Medicine of South Africa 2009, 8(II):24-35.

10. Seeff LB: Natural history of chronic hepatitis C. Hepatol 2002 , 36:S35-S46.

II. Shepard CW, Finelli L, Alter MJ: Global epidemiology of hepatitis C virus infection. Lancet Infect Dis 2005, 5:558-567.

12. Lauer GM, Walker BD: Hepatitis C virus infection. N EnglJ Med 200I, 345:4I-52.

13. Alter MJ: Epidemiology of Hepatitis C. Hepatol I997, 26:62S-65S.

14. Dusheiko GM: The natural course of chronic hepatitis C: implications for clinical practice. J Viral Hepat 1998, 5(SI):9-12.

15. Ikeda K, Saitoh S, Suzuki Y, Kobayashi M, Tsubota A, Koida I, Arase Y, Fukuda M, Chayama K, Murashima N, Kumada H: Disease progression and hepatocellular carcinogenesis in patients with chronic viral hepatitis: a prospective observation of 2215 patients. J Hepatol 1998, 28:930-938.

16. Akuta N, Chayama K, Suzuki F, Someya T, Kobayashi M, Tsubota A, Suzuki Y, Saitoh S, Arase Y, Ikeda K, Kumada H: Risk factors of hepatitis $C$ virus-related liver cirrhosis in young adults: positive family history of liver disease and transporter associated with antigen processing 2(TAP2)*020 I Allele. J Med Virol 200I, 64:109-116.

17. Fattovich G, Stroffolini T, Zagni I, Donato F: Hepatocellular carcinoma in cirrhosis: incidence and risk factors. Gastroenterol 2004, I 27(SI):S35-50.

18. National Institutes of Health: Management of Hepatitis C National Institutes of Health Consensus Development Conference Panel Statement On-Line; 1997.

19. Lopez C: Secret killers: hepatitis $\mathbf{C}$ virus infection in perspective. In Health in the Commonwealth, Challenges and Solutions Kensington Publ. Ltd; 1999.

20. Soni PN, Tait DR, Gopaul W, Sthar MA, Simjee AE: Hepatitis C virus infection in chronic liver disease in Natal. S Afri Med J 1996, 86:80-83.

21. Alberti A, Morsica G, Chemello L, Cavalletto D, Noventa F, Pontisso $P$, Ruol A: Hepatitis C viraemia and liver disease in symptomfree individuals with anti-HCV. Lancet 1992, 340:697-698.

22. Gangaidzo IT, Moyo VM, Khumalo H, Saungweme T, Gomo ZAR, Ronalt T, Gordeuk VR: Hepatitis C virus in Zimbabwe. Cent Afr J Med 1997, 43:122-125. 
23. Olubuyide IO, Aliyu B, Olalelye OA, Ola SO, Olawuyi F, Malabu UH, Odemuyiwa SO, Odaibo GN, Cook GC: Hepatitis B and C virus and hepatocellular carcinoma. Trans R Soc Trop Med Hyg 1997, 91:38-4I.

24. Sherlock S, Dooley J: Diseases of the liver and biliary system Tenth edition. Blackwell Science Ltd; 1997:53 I-546.

25. Fattovich G, Pantalena M, Zagni I, Realdi G, Schalm SW, Christensen E: European Concerted Action on Viral Hepatitis (EUROHEP). Effect of hepatitis B and $C$ virus infections on the natural history of compensated cirrhosis: a cohort study of $\mathbf{2 9 7}$ patients. Am J Gastroenterol 2002, 97:2886-2895.

26. Aizawa Y, Shibamoto Y, Takagi I, Zeniya M, Toda G: Analysis of factors affecting the Appearance of Hepatocellular Carcinoma in Patients with Chronic Hepatitis C: A long term follow up study after Histologic Diagnosis. Cancer 2000, 89:53-58.

27. Kew MC, Houghton M, Choo QL, Kuo G: Hepatitis C antibodies in Southern African blacks with hepatocellular carcinoma. Lancet 1990, 335:873-874.

28. Liaw YF, Chu CM: Hepatitis B virus infection. Lancet 2009, 373:582-592.

29. Raimondo G, Navarra G, Mondello S, Costantino L, Colloredo G, Cucinotta E, Di Vita G, Scisca C, Squadrito G, Pollicino T: Occult hepatitis B virus in liver tissue of individuals without hepatic disease. J Hepatol 2008, 48:743-746.

30. Trevisani F, D'Intino PE, Grazi GL, Caraceni P, Gasbarrini A, Colantoni A, Stefanini GF, Mazziotti A, Gozzetti G, Gasbarrini G, Bernardi $M$ : Clinical and pathologic features of hepatocellular carcinoma in young and older Italian patients. Cancer 1996, 77:2223-2232

31. Zuckerman AJ: Viral hepatitis. Transfus Med 1993, 3:7-19.

32. Arshard H, Malike H, William L: Chronic hepatitis B virus infection: treatment strategies for the next millennium. Ann Intern Med 2000, 132:723-731.

33. Weining M, Harkim JG, Gudza I, Tobaiwa O: Hepatitis C virus and HIV antibodies in patients with hepatocellular carcinoma in Zimbabwe: a pilot study. Trans Roy Soc Trop Med and Hyg 1997, 91:570-572.

34. Barth H, Liang TJ, Baumert TF: Hepatitis C virus entry: molecular biology and clinical implications. Hepato 2006, 44:527-535.

35. Hann HW: Hepatocellular carcinoma in Asian Americans. Cancer 1998, 83:1723-1727.

36. Webster G, Barnes E, Brown D, Dusheiko G: HCV genotypes: role in pathogenesis of disease and response to therapy. Baillieres Best Pract Res Clin Gastroenterol 2000, 1 4:229-240.

37. Chirara MM: Epidemiology of the Hepatitis $B$ virus and the determination of the surface antigen gene nucleotide sequence. A. PhD thesis University of Zimbabwe; 1993.

38. Okada K, Okada H: Primary Liver cell carcinoma Volume 2. Edited by: Neil Mcinyre. Oxford Textbook of Clinical Hepatology; 1997:1019-1052.

39. Nyathi CB, Mutiro CF, Hasler JA, Chetsanga CJ: Human exposure to aflatoxins in Zimbabwe. Cent Afr J Med 1989, 35:542-545.

Publish with Bio Med Central and every scientist can read your work free of charge

"BioMed Central will be the most significant development for disseminating the results of biomedical research in our lifetime. "

Sir Paul Nurse, Cancer Research UK

Your research papers will be:

- available free of charge to the entire biomedical community

- peer reviewed and published immediately upon acceptance

- cited in PubMed and archived on PubMed Central

- yours - you keep the copyright

Submit your manuscript here:

http://www.biomedcentral.com/info/publishing_adv.asp
BioMedcentral 